\title{
Biological Analogs of Infrainguinal Arteries: Evolution and Development Prospects (Review)
}

DOI: $10.17691 / \mathrm{stm} 2017.9 .4 .27$

Received August 16, 2017

I.Y. Zhuravleva, MD, DSc, Professor, Head of Bioprosthesis Laboratory';

A.S. Zhuravleva, Student, Medical Faculty2;

M.O. Zhulkov, Resident Medical Practitioner';

N.P. Aleshkovich, Researcher, Bioprosthesis Laboratory';

A.M. Karaskov, MD, DSc, Academician of the Russian Academy of Sciences, Director ${ }^{1}$

${ }^{1}$ Meshalkin Siberian Biomedical Research Center of the Ministry of Health of the Russian Federation,

15 Rechkunovskaya St., Novosibirsk, 630055, Russian Federation;

${ }^{2}$ Novosibirsk State University, 2 Pirogova St., Novosibirsk, 630090, Russian Federation

Currently, the gold standard of plastic material for infrainguinal artery replacement is still autovein, however, not infrequently the necessity for prostheses arises.

The review presents the characteristics of xeno- and allogenic prostheses for lower limb arteries, which have been used in vascular surgery worldwide since 1960-ies till the present.

There have been analyzed the clinical results with the bioprostheses, their advantages and disadvantages being discussed. We have shown that the approach based on chemically cross-linked human and animal tissues used for bioprostheses is limited in its further development.

We have studied the evolution of tissue engineering vascular grafts (TEVG), and carried out a critical review of current state of the issue, and presented further paths of its development.

Key words: lower limb arteries; arterial bioprostheses; vascular tissue engineering.

\section{Relevancy of the problem}

The main cause of the stenosis of lower limb arteries (infrainguinal arteries, IAr) is atherosclerosis, its incidence increasing annually [1]. Currently, a minimally invasive surgery like as balloon angioplasty and stent implantation is possible in most patients [2]. Nevertheless, the majority of patients underwent surgery procedures consisting in the replacement of a damaged artery by either prosthesis or an autogenous $v$. saphena magna, it still being a gold standard of efficiency in such reconstructions [3]. However, considering predominantly multifocal character of atherosclerotic damage, an autovein is used primarily for coronary artery bypass grafting. For this reason, as well as due to some anatomical peculiarities of $v$. saphena magna (disseminated vein type), it is a prosthesis that is used most frequently [4].

Prostheses made of synthetic materials - Dacron and polytetrafluorethylene (PTFE) - are known to demonstrate good long-term results, if the diameter of a reconstructed artery is over $6 \mathrm{~mm}$; however, these prostheses are contraindicated for bypass grafting of the arteries with a diameter of less than $4 \mathrm{~mm}$ [5]. Lower limb arteries are somewhere between: the diameter of the femoral artery in the area of proximal anastomosis is 6-7 $\mathrm{mm}$; the popliteal artery $-5 \mathrm{~mm}$, if the anastomosis is above the knee joint space, and $4 \mathrm{~mm}$ - below the knee joint space; for tibial and peroneal arteries an optimal diameter of bypass should not exceed $3.5 \mathrm{~mm}$.

Within several decades the question is still open: what prosthesis type and model should be regarded as optimal

For contacts: Irina Y. Zhuravleva, e-mail: juravl_irina@mail.ru 
for IAr reconstruction? The key measure is primary patency rate: the absence of restenosis in a long-term (at least 5 years) postoperative period. In secondary patency rate, when the bypass function is restored by means of various procedures - angioplasty, stenting, anastomosis repair, etc. - the graft characteristics are less indicative. Needless to say, that the best primary patency rate is demonstrated by autogenous vein.

Concerning prostheses of different types, randomized studies are necessary, since it is extremely difficult to compare the findings of different vascular centers: patients' composition on comorbidities, the state of inflow and outflow tracts differ dramatically. However, the patency rate of any bypasses including autovein are well known to be significantly higher in patients with persistent blood flow in three crural arteries compared to patients with two or even one arteries occluded.

Available literature covers insufficiently the effects of bioprostheses. Moreover, there are no data on large randomized studies. The authors of one metaanalysis published in 2017 have shown that generally, bioprostheses outperform the analogs made of PTFE in long-term patency, however, there is no information available for evidence-based opinion [6].

Current state of biomedical sciences holds out a hope of developing within the near decade clinically available tissue engineering constructions including those to substitute damaged vessels of various locations [7]. However, even now, breakthroughs in the development of tissue engineering analogs of low limb arteries and near-term prospects require analysis.

In this regard, our survey research aims at studying clinical consequences of using different biological prostheses of lower limb arteries, as well as estimating the prospects of tissue engineered vessels.

\section{The evolution of bioprostheses of infrainguinal arteries}

The first serious but though failed attempt to develop $\mathrm{IAr}$ bioprosthesis were the researches carried out in 50-60ies of the last century [8-10]. The authors used bovine carotid artery treated with proteolytic enzyme ficin - with the following preservation in formaldehyde. Further variations of the artery treatment methods consisted in the substitution of a cross-linking agent for a bifunctional one - dialdehyde starch or glutaraldehyde, the treatment process being made more complex [1113]. Bioprostheses Solcograft and Solcograft-P based on the ideas by Rosenberg were tested in patients [8, 11] including multicenter studies with the number of patients over $100[12,13]$. The authors considered these bioprostheses to be a reasonable alternative to synthetic analogs; however, secondary patency rate was only $50-60 \%$ in 4 years, while the incidence of aneurysms was $36-42 \%$. The studies by Holdsworth et al. [13] drew a line in clinical application of bioprostheses made of bovine carotid artery. It is most likely that failures were due to both: mismatch of the bioprosthesis and reconstructed artery diameters (bioprosthetic diameter was 7.5-14 mm [9], while the diameter of femoropopliteal arterial segment was 4-7 mm), and also the treatment method (dialdehydes impart rigidity and hydrophobic properties to biomaterial, that has an adverse effect on biomechanical and functional characteristics of a flow in the repair area).

Bioprosthesis made of human umbilical cord vein preserved in glutaraldehyde (HUV bioprosthesis, or BioGraft) developed by Dardick in 1974 has left a significant mark in the history of vascular surgery [14]. From 1975 to 1989 Meadox Medicals, Inc. (USA) was engaged in manufacturing the bioprosthesis [15]. BioGraft demonstrated good primary patency rate: 50 $60 \%$ within a period up to 3 years, and $42-50 \%$ within the period up to 6 years [16-18]. Randomized studies involving over 200 patients have proved that primary patency rate of HUV bioprosthesis is significantly higher than that of synthetic prostheses made of PTFE [18-20]. The major drawback of BioGraft, according to different researchers [16, 21, 22] was high incidence rate of aneurysms and biodegradation: $8-17 \%$. As a result, Dardick et al. carried out investigations to reveal the aneurysm causes [23], and invented external support in the form of total covering of biomaterial by Dacron mesh. The product is known as second generation HUV bioprosthesis, and in 1989 the rights to it were transferred to BioVascular Inc., which further realized its manufacture. Modifications made in the bioprosthesis design had a positive effect on clinical results: 6-year primary patency rate increased by $14 \%$ [24], while aneurysm incidence decreased up to $2.9-3.5 \%[24,25]$.

In 2011 Ziegler et al. [26] published their analytical review summarizing the experience with infrainguinal reconstructions using various types of arterial prostheses. The data presented in the review shows an autovein to exhibit the best results (see the Table). Most worldwide PTFE prostheses show satisfactory results only in femoropopliteal above knee reconstructions. HUV bioprostheses are intermediate between an autovein and synthetic prostheses, and can be used for IAr reconstruction in case a patient has no adequate autovein. However, in 2005 FDA put a veto on manufacture and application of human tissue products [15].

Currently, in world market there are bioprostheses of two types. One of them - Omniflow II - is marketed as a biosynthetic prosthesis of sheep collagen, which is glutaraldehyde-treated. To obtain this prosthesis, polyester mesh put on a silicone rod is placed under the skin in adult sheep for 12-14 weeks. During this period the donor animal collagen covers tightly and grows out of the polymer mesh, the implant is extracted and preserved by glutaric aldehyde [27]. The authors of this technology are Ketharanathan and Christie [28]. In 1983, after successful preclinical and clinical trials, Australian company BioNova began to produce Omniflow bioprostheses for vascular surgery [27]. 
There is very scanty data on clinical results with Omniflow II bioprosthesis. The considerable experience on its usage in 274 patients was presented by Koch et al. $[29,30]$. The authors estimate the results as satisfactory, though 5-year primary patency rate even in persistent crural outflow paths was $45 \%$ in femoro-popliteal above knee bypass, and $40 \%$ - in femoro-popliteal below knee bypass, that is significantly worse of aggregate data (not specified by subgroups depending on crural outflow paths) obtained when implanting HUV bioprosthesis (see the Table). If one crural artery was retained, the patency rate was 27 and $17 \%$, respectively. Most researchers believe Omniflow II application to be feasible only under the conditions of infected reconstructed area [31-33], since biomaterials due to no surgical porosity are more resistant to contamination compared to porous synthetic materials. However, other authors, who have obtained negative results, criticize harshly this arterial prosthesis, they consider its application to be unreasonable [34, 35].

ProCol bioprosthesis is the second presented at the market and less studied. It is made of bovine mesenteric vein and treated by glutaraldehyde. Schmidli et al. [36] used it for infrainguinal reconstructions in 32 patients, and received poor results: primary patency rate in a month was 16\%; secondary (a year later) was $26 \%$. Prosthetic aneurysms were found in $6 \%$ cases within a year and a half. Currently, the prosthesis is recommended only as an arterio-venous shunt for dialysis patients. However, LeMaitre Vascular (USA) accrued a right to Omniflow II (in 2014) and ProCol (in 2016) bioprostheses, and is extensively marketing them worldwide [37].

In Russia, a biological KemAngioprosthesis (NeoCor, Kemerovo, Russia) has been used in vascular surgery since 1993. It is made from bovine internal thoracic artery preserved by epoxy compound and modified with heparin.

The development of this bioprosthesis was based on the researches started in 1987 by Nojiri et al. [38], those progressed rapidly in the late 80 -ies and early 90-ies of the last century. Epoxy compounds, used as an alternative to glutaraldehyde for cross linkage of xenogenic-artery collagen, have attracted close attention of researchers, since biomaterial treated with epoxides acquires hydrophilic and elastic properties, close to those natural arteries have, as well as high resistance to calcification [39]. In 1993 Baxter International (USA) announced the entry into market of novel arterial bioprosthesis Denaflex treated with polyepoxy preserving agent Denacol-313 [40]. However, the bioprosthesis has never entered the market. A failed attempt to implement Denaflex in clinical practice was probably due to the fact that all researchers worked with epoxy mixtures Denacol (Nagase Ltd., Japan) having many toxic impurities because of technical purification grade. In Russia, epoxy preserving agent ethylene glycol diglycidyl ether has $97.5-99 \%$ purity. It is synthesized as a commercial product by N.N. Vorozhtsov Novosibirsk Institute of Organic Chemistry of Siberian Branch of Russian Academy of Sciences.

The experience accumulated by Russian vascular surgeons with epoxy-treated infrainguinal bioprostheses has been embodied in some works [41-49]. In general, the authors consider the findings as satisfactory and recognize KemAngioprosthesis to be a reasonable alternative to an autovein in femoro-popliteal above knee position, and a prosthesis of choice for femoropopliteal below knee reconstruction, when an autovenous transplant is unavailable. So, the largest study [41] devoted to the 12-year results with 315 KemAngioprosthesis showed that their 6-year patency rate in femoro-popliteal above knee position is $60.3 \%$ that is comparable with the results obtained with HUV bioprostheses (see the Table). In their later researches the authors showed that the results of IAr prosthetic reconstructions can be improved by two approaches. The first one is bioprosthetic treatment improving: namely, substitution of unfractionated heparin for low-molecularweight enoxaparin [48]. The second approach is to influence such risk factors as platelet hyperaggregation and inflammatory response [49]. However, the problem of aneurysm formation arising when using all biological prostheses is typical for KemAngioprosthesis as well. The complication rate is $1.9-7.0 \%[41,47]$.

Thus, in modern reconstructive surgery, autovenous transplants, synthetic and biological prostheses are used to replace affected infrainguinal arteries. None of these substitutes is an ideal alternative to a natural artery; all of them, to some extent, are susceptible to complications requiring redo surgery or limb amputation.

\section{Tissue-engineered arteries: an alternative to vascular prostheses?}

The use of regenerative medicine approaches, a tissue-engineering construction implanted in the compromised area in particular, could be an optimal decision for IAr substitution, and complete or partial recovery of a natural artery due to living self-renewing tissue in prospect.

For this purpose a tissue engineering vascular graft 
(TEVG) should meet a number of strong requirements $[50,51]$ :

1) at an initial stage: effectively withstand and compensate mechanical loading of a blood flow with minimal or no leakages through the wall; the relation between elasticity, extensibility and mechanical strength characteristics should be adjusted so that there would be no deformities and pressure gradients in the reconstruction area [52-56];

2) to cause no unfavorable reactions, primarily an immune response; when making a graft, the materials should be nontoxic for surrounding tissues and cells, since they participate in its filling $[57,58]$;

3) a graft inner layer, which is in direct contact with blood, should be thrombo-resistant [57];

4) to be easy-to-use: long maintenance of sterility, no specific transportation terms and storage conditions, ease handling of a product in surgical procedures when implanted. All these aspects will play an important role in the formation of commercial TEVG market [59];

5 ) it is crucial for tissue engineering constructions based on bioresorbable matrices to be completely substituted by living cellular and extracellular structures $[60,61]$.

Approaches to the development of tissue engineering vessels. There are two approaches to TEVG, which are similar in sequence: matrix creation $\rightarrow$ cellular filling of a matrix $\rightarrow$ self-organization of a structure in response to environmental and internal conditions into a viable graft, which closely resembles a replaced vessel in anatomical and functional characteristics. The first approach consists in filling a graft by cells in vitro before implantation, the second approach - the same process in a recipient's body.

The key moment of the first approach efficiency is an adequate choice of cells for culturing; as a rule, stem cells are used [62]: mononuclear and mesenchymal bone marrow [63-68], muscular [69], induced pluripotent $[70,71]$, adipose-derived mesenchymal stem cells [72-74]. Some researchers also use fibroblasts [75, 76]; however, their regenerative potential is limited, and their usage is impeded, since it is difficult to match an appropriate tissue, which can be incised for further work with cells [77-79].

Two variants are possible: autocellular - acquisition of recipient's cells; allocellular [80] — donor cells meeting histocompatibility requirements. Cell cultures are placed in a bioreactor, where they gradually fill a porous matrix in conditions imitating blood flow.

Bioreactor approach is attractive for a surgeon and a recipient as it enables to obtain a ready cultured vessel, which is just to be implanted in an affected area. However, sampling and culture of stem cells (and in case of an allo-cell resource - search for a donor) are rather labor-intensive procedures and require heavy time and financial expenses [81]. The storage life of "bioreactor" TEVG is limited, and special conditions are needed to maintain cell viability [82-84]. Moreover, at the current stage of scientific development "bioreactor" TEVG fails to culture an adequately organized vessel even under controlled conditions of a bioreactor [85].

Another approach consists in the use of cell-free matrices, which are to be inhabited by cells in situ in a recipient's body. Consequently, there is no need to look for a donor - cell resource is always autogenous. Moreover, acellular grafts require no cell culture therefore, the fabrication technique is simplified, and a sterile storage period increases, so the prime cost reduces, and a product becomes available for clinical practice [86]. In such approach, all attempts of researchers are concentrated on creating an optimal matrix.

Matrices for tissue engineering constructions. The very first studies were devoted to synthetically nondegradable matrices. Zilla et al. in 1987 reported about successful human implantation of PTFE prostheses with an internal surface endothelialized in vitro [87]. Then the technique was improved [88], and in 2009 the authors in the study shared their 15-year experience of using such prostheses in 318 patients, who had been operated on a femoro-popliteal segment. 10-year patency generally was $61 \%$ [89] that seems to be as good as the results of autovenous reconstructions. However, despite proven efficiency, the current approach is not of high-priority, since non-degradable matrices are unlikely to have regeneration potential: they are unable to achieve the main goal - to create an adequate living artery in situ to substitute an affected segment [90].

In parallel with studying synthetic non-degradable matrices, decellularized allo- and xenogenous arteries were being under study as well. Despite the variability of decellularization protocols, the approach consists in destroying and removing donor cells followed by chemical cross-linking of extracellular matrix, which prevents its degradation in the recipient's body; after that the construction is exposed to cell filling. The supporters of the approach think the key advantage to be in the fact that it enables to avoid constructing a complex structure of extracellular matrix de novo [90]. A key disadvantage of the technique is the instability of nonresorbable matrix combined with high immunogenicity of xenomaterial: decellularized vascular grafts are proved to provoke acute and chronic inflammation [91, 92].

The next spiral of elaboration was a bioresorbable matrix. For its fabrication, synthetic and natural polymers are chosen, as when degrading they enable new tissue formation in course of time. The most frequently used synthetic polymers are polycaprolactone (PCL), polyglycolic acid (PGA), polyester of glycerol and sebacic acid (PGS), polyester of urethane-urea (PEUU); natural polymers are fibrin, silk fibroin, collagen, elastin, chitosane, alginate, and their various combinations [86, 93, 94]. The authors of some relatively recent studies have combined both polymer types in an attempt to achieve optimal properties of each tissue layer [60, 95-98]. 
There are several methods to fabricate bioresorbable matrices, which are based on porous polymers [99] or films, which are then rolled [100]. However, the most popular technique is still electrospinning. When using electrospinning, a polymer jet is exposed to electrostatic forces, and the setting solid polymer on the collector forms an amorphous three-dimensional filament net, which resembles an extracellular matrix [101].

With time "frameless" techniques for TEVG formation have appeared. The so-called "self-assembly" was the first method historically: a two-dimension cell layer is folded around the core forming a tube of a future graft [102]. When the approach appeared, new methods started emerging, such as: cell printing [103] and the formation of "micro-tissue aggregates" - cell groups placed in a form where they eventually form the tubular structure of a vessel.

Currently, most studies are carried out on model animals: mice, pigs, sheep, dogs [104]. Only some tissue engineering constructions have accomplished clinical testing. In particular, a research team - the pioneers in the field (Dahl et al.) - improved the initial "synthetic matrices/bioreactor" approach by exposing a developed graft to decellularization, the cells being selectively destroyed, but the extracellular matrix they formed remained. The technique was clinically approved in 2012; TEVG were implanted to 10 patients, their primary patency was $78 \%$ in a month, and $60 \%-6$ months later [59]. The long-term results are still pending.

Unsolved problems of vascular tissue engineering. Natural vessels are known to consist of three layers and the membranes, which separate them, while current models are confined to one- or two-layer grafts. In itself it limits the graft capacity to adapt to micro-environment and reproduce de novo three-layer architectonics.

The more complex problem is a selective cell filling of the implanted scaffold - i.e., the occupation of each functional vascular layer by a required cell type: intima should be inhabited by endotheliocytes, and media and adventitium - by smooth muscular cells and fibroblasts. Up to now, no area of medicine has directional simulation of regeneration, and vascular tissue engineering is no exception. The trend, which is called "matrix functionalization", is being rapidly developed now; however, there are still more questions rather than answers.

One more problem is the absence of an adequate model for TEVG testing. Currently, none of the model organisms under use has been found to be optimal due to variations from human in many parameters - from physiological and to the composition and structure of signal molecules [105-107].

\section{Conclusion}

An autologous vena saphena magna is considered to be a gold standard of flexible material to repair infrainguinal arteries for vascular surgeons in everyday practice. However, frequently, it is necessary to use prostheses. Bioprostheses show better patency efficiency compared to synthetic ones, but it does not solve the problem of adequate arterial substitution. The invention of tissue engineering constructions which are able to transform in a natural artery can become a comprehensive solution.

Still, there has been found no method to create tissue engineering vessels suited for practice, despite the abundance of researches and suggested approaches. We are to comprehend how an ideal graft ready for widespread practical use looks like. Most probably, adequate cost of a graft, its usability and safety for patients, as well as a minimized number of possible side effects are sure to be the main competitive advantages at a stage of tissue engineering vessel market formation [59].

Now it is evident that the developments in tissue engineering will gradually become everyday medical practice $[108,109]$. Therefore, it is necessary to monitor continuously changing data on clinical and preclinical trials, review the demands placed on tissue engineering grafts, take into consideration economical and ethical factors when implementing novel developments. It is very important even now to remember about a notable approach in personalized medicine: a patient should be involved in decision making when choosing an implant. The role of such "personalization" factor will play the more and more notable role in the future $[110,111]$.

Foreign researchers are developing various approaches to TEVG creation. In Russia the trend is still underdeveloped. And due to this fact the qualityprice ratio of most tissue engineering products are likely to exceed the threshold of availability. However, some developments have been started, and it is hoped that with time researchers will overcome the difficulties [112, 113].

Future belongs to modern developments in regenerative medicine. Now it is unclear which of them will become everyday practice. But one thing is practically assured: tissue engineering is the field of medicine, which is steadily transferring from a world of ideas into a world of real, tangible and promising results.

Study Funding. This study was not supported by any financial sources.

Conflicts of Interest. The authors declare no conflicts of interest related to the present study.

\section{References}

1. Dermody M., Homsy C., Zhao Y., Goodney P.P., Estes J.M. Outcomes of infrainguinal bypass determined by age in the Vascular Study Group of New England. J Vasc Surg 2015; 62(1): 83-92, https://doi.org/10.1016/j.jvs.2015.02.020.

2. Barkat M., Torella F., Antoniou G.A. Drug-eluting balloon catheters for lower limb peripheral arterial disease: the evidence to date. Vasc Health Risk Manag 2016; 12: 199-208, https://doi.org/10.2147/vhrm.s62370.

3. Heo S.H., Park Y.J., Woo S.Y., Kim D.I., Kim Y.W. 
Comparison of long-term results of above-the-knee femoro-popliteal bypass with autogenous vein and polytetrafluoroethylene grafts. Ann Surg Treat Res 2015; 88(1): 28-34, https://doi.org/10.4174/astr.2015.88.1.28.

4. Pulli R., Dorigo W., Guidotti A., Fargion A., Alessi Innocenti A., Pratesi $C$. The role of infrainguinal bypass surgery in the endovascular era. Ann Vasc Dis 2014; 7(1): 7-10, https://doi.org/10.3400/avd.ra.13-00124.

5. Xue L., Greisler H.P. Biomaterials in the development and future of vascular grafts. J Vasc Surg 2003; 37(2): 472480, https://doi.org/10.1067/mva.2003.88.

6. Wilasrusmee C., Siribumrungwong B., Horsirimanont S., Poprom N., Jirasiritham J., Thakkinstian A. Clinical results of biologic prosthesis: a systematic review and meta-analysis of comparative studies. Ann Med Surg (Lond) 2017; 15: 26-33, https://doi.org/10.1016/j.amsu.2017.01.018.

7. Emmert M.Y., Fioretta E.S., Hoerstrup S.P. Translational challenges in cardiovascular tissue engineering. $J$ Cardiovasc Trans/ Res 2017; 10(2): 139-149, https://doi.org/10.1007/ s12265-017-9728-2.

8. Rosenberg N., Martinez A., Sawyer P.N., Wesolowski S.A., Postlethwait R.W., Dillon M.L. Jr. Tanned collagen arterial prosthesis of bovine carotid origin in man. Preliminary studies of enzyme-treated heterografts. Ann Surg 1966; 164(2): 247-256, https://doi.org/10.1097/00000658196608000-00010.

9. Haimov M., Jacobson J.H. 2nd. Experience with the modified bovine arterial heterograft in peripheral vascular reconstruction and vascular access for hemodialysis. Ann Surg 1974; 180(3): 291-295, https://doi.org/10.1097/00000658197409000-00006.

10. Dale W.A., Lewis M.R. Modified bovine heterografts for arterial replacement. Ann Surg 1969; 169(6): 927-945, https:// doi.org/10.1097/00000658-196906000-00013.

11. Sawyer P.N., Fitzgerald J., Kaplitt M.J., Sanders R.J., Williams G.M., Leather R.P., Karmody A., Hallin R.W., Taylor R., Fries C.C. Ten year experience with the negatively charged glutaraldehyde-tanned vascular graft in peripheral vascular surgery. Initial multicenter trial. Am J Surg 1987; 154(5): 533537, https://doi.org/10.1016/0002-9610(87)90272-8.

12. Schröder A., Imig H., Peiper U., Neidel J., Petereit A. Results of a bovine collagen vascular graft (Solcograft-P) in infra-inguinal positions. Eur J Vasc Surg 1988; 2(5): 315-321, https://doi.org/10.1016/s0950-821x(88)80007-0.

13. Holdsworth R.J., Naidu S., Gervaz P., McCollum P.T. Glutaraldehyde-tanned bovine carotid artery graft for infrainguinal vascular reconstruction: 5-year follow-up. Glutaraldehyde-tanned bovine carotid artery graft for infrainguinal vascular reconstruction: 5-year follow-up. Eur J Vasc Endovasc Surg 1997; 14(3): 208-211, https://doi. org/10.1016/s1078-5884(97)80193-1.

14. Dardik H., Dardik I.I. Successful arterial substitution with modified human umbilical vein. Ann Surg 1976; 183(3): 252-258, https://doi.org/10.1097/00000658-197603000-00006.

15. Dardik H. A 30-year odyssey with the umbilical vein graft. J Am Coll Surg 2006; 203(4): 582-583, https://doi. org/10.1016/j.jamcollsurg.2006.07.003.

16. Dardik H., Miller N., Dardik A., Ibrahim I., Sussman B., Berry S.M., Wolodiger F., Kahn M., Dardik I. A decade of experience with the glutaraldehyde-tanned human umbilical cord vein graft for revascularization of the lower limb. $J$ Vasc Surg 1988; 7(2): 336-346, https://doi.org/10.1016/07415214(88)90153-x.
17. Raithel D., Schweiger H., Gentsch H.H. Late results with Dardik-biograft in peripheral arterial surgery. J Cardiovasc Surg (Torino) 1984; 25(3): 222-224.

18. Eickhoff J.H., Broomé A., Ericsson B.F., Buchardt Hansen H.J., Kordt K.F., Mouritzen C., Kvernebo K., Norgren L., Rostad H., Trippestad A. Four years' results of a prospective, randomized clinical trial comparing polytetrafluoroethylene and modified human umbilical vein for below-knee femoropopliteal bypass. J Vasc Surg 1987; 6(5): 506-511, https://doi.org/10.1016/0741-5214(87)90311-9.

19. McCollum C., Kenchington G., Alexander C., Franks P.J., Greenhalgh R.M. PTFE or HUV for femoropopliteal bypass: a multi-centre trial. Eur J Vasc Surg 1991; 5(4): 435-443.

20. Johnson W.C., Lee K.K. A comparative evaluation of polytetrafluoroethylene, umbilical vein, and saphenous vein bypass grafts for femoral-popliteal above-knee revascularization: a prospective randomized Department of Veterans Affairs cooperative study. J Vasc Surg 2000; 32(2): 268-277, https://doi.org/10.1067/mva.2000.106944.

21. Karkow W.S., Cranley J.J., Cranley R.D., Hafner C.D., Ruoff B.A. Extended study of aneurysm formation in umbilical vein grafts. J Vasc Surg 1986; 4(5): 486-492, https://doi. org/10.1067/mva.1986.avs0040486.

22. Strobel R., Boontje A.H., Van Den Dungen J.J. Aneurysm formation in modified human umbilical vein grafts. Eur J Vasc Endovasc Surg 1996; 11(4): 417-420, https://doi. org/10.1016/s1078-5884(96)80173-0.

23. Dardik H., Ibrahim I.M., Sussman B., Kahn M., Sanchez M., Klausner S., Baier R.E., Meyer A.E., Dardik I.I. Biodegradation and aneurysm formation in umbilical vein grafts: observations and a realistic strategy. Ann Surg 1984; 199(1): 61-68, https://doi.org/10.1097/00000658-19840100000011.

24. Dardik H., Wengerter K., Qin F., Pangilinan A., Silvestri F., Wolodiger F., Kahn M., Sussman B., Ibrahim I.M. Comparative decades of experience with glutaraldehydetanned human umbilical cord vein graft for lower limb revascularization: an analysis of 1275 cases. J Vasc Surg 2002; 35(1): 64-71, https://doi.org/10.1067/mva.2002.121053.

25. Neufang A., Espinola-Klein C., Dorweiler B., Messow C.M., Schmiedt W., Vahl C.F. Femoropopliteal prosthetic bypass with glutaraldehyde stabilized human umbilical vein (HUV). J Vasc Surg 2007; 46(2): 280-288, https://doi.org/10.1016/j.jvs.2007.03.054.

26. Ziegler K.R., Muto A., Eghbalieh S.D.D., Dardik A. Basic data related to surgical infrainguinal revascularization procedures: a twenty year update. Ann Vasc Surg 2011; 25(3): 413-422, https://doi.org/10.1016/j.avsg.2010.10.010.

27. Edwards G.A., Roberts G. Development of an ovine collagen-based composite biosynthetic vascular prosthesis. Clin Mater 1992; 9(3-4): 211-223, https://doi. org/10.1016/0267-6605(92)90102-y.

28. Ketharanathan V., Christie B.A. Glutaraldehyde-tanned ovine collagen conduits as vascular xenografts in dogs. Arch Surg 1980; 115(8): 967-969, https://doi.org/10.1001/ archsurg.1980.01380080057011.

29. Koch G., Gutschi S., Pascher O., Fruhwirth J., Hauser H. Femoropopliteal vascular replacement: vein, ePTFE or ovine collagen? Zentralb/ Chir 1996; 121(9): 761-767.

30. Koch G., Gutschi S., Pascher O., Fruhwirth H., Glanzer H. Analysis of 274 Omniflow vascular prostheses implanted over an eight-year period. Aust $N$ Z J Surg 1 
997; 67(9): 637-639, https://doi.org/10.1111/j.1445-2197.1997. tb04614.x.

31. Neufang A., Dorweiler B., Espinola-Klein C., Savvidis S., Doemland M., Schotten S., Vahl C.F. Outcomes of complex femorodistal sequential autologous vein and biologic prosthesis composite bypass grafts. J Vasc Surg 2014; 60(6): 1543-1553, https://doi.org/10.1016/j.jvs.2014.07.103.

32. Töpel I., Uhl C., Ayx I., Steinbauer M. Xenografts in septic vascular surgery. Gefasschirurgie 2016; 21(Suppl 2): S55-S58, https://doi.org/10.1007/s00772-016-0160-8.

33. Krasznai A.G., Snoeijs M., Siroen M.P., Sigterman T., Korsten A., Moll F.L., Bouwman L.H. Treatment of aortic graft infection by in situ reconstruction with Omniflow II biosynthetic prosthesis. Vascular 2016; 24(6): 561-566, https://doi. org/10.1177/1708538115621195.

34. Fink M., Lesnik G., Wandschneider W. Materialermüdung und Degeneration der Omniflow-IIM Prothese. Wien klin Mag 2015; 18(3): 78-85, https://doi. org/10.1007/s00740-015-0054-5.

35. Bozoglan O., Mese B., Eroglu E., Elveren S., Gul M., Celik A., Yildirimdemir H.I., Ciralik H., Yasim A. Which prosthesis is more resistant to vascular graft infection: polytetrafluoroethylene or Omniflow II biosynthetic grafts? Surg Today 2016; 46(3): 363-370, https://doi.org/10.1007/s00595015-1141-3.

36. Schmidli J., Savolainen H., Heller G., Widmer M.K., Then-Schlagau U., Baumgartner I., Carrel T.P. Bovine mesenteric vein graft (ProCol) in critical limb ischaemia with tissue loss and infection. Eur J Vasc Endovasc Surg 2004; 27(3): 251-253, https://doi.org/10.1016/j.ejvs.2003.12.001.

37. LeMaitre Vascular. URL: http://lemaitre.gcs-web.com/.

38. Nojiri C., Noishiki Y., Koyanagi H. Aorta-coronary bypass grafting with heparinized vascular grafts in dogs. A preliminary study. J Thorac Cardiovasc Surg 1987; 93(6): 867-877.

39. Tomizawa Y., Noishiki Y., Okoshi T., Miyata T., Koyanagi $\mathrm{H}$. Development of a small caliber biologic vascular graft: evaluation of its antithrombogenicity and the early healing process. ASAIO Trans 1990; 36(3): M734-M737.

40. Wang E.Y., Giclas P.C., Tu R.H., Hata C., Quijano R.C. A comparative study of complement activation by Denaflex, Bioflow, and BioPolyMeric vascular grafts. ASAIO J 1993; 39(3): M691-M694, https://doi.org/10.1097/00002480-19933903000103.

41. Barbarash L.S., Ivanov S.V., Zhuravleva I.Yu., Anufriev A.I., Kazachek Ya.V., Kudriavtzeva Yu.A., Zinetz M.G. Twelve-year experience of bioprosthesis implantation into infrainguinal arteries. Angiologiya $i$ sosudistaya khirurgiya 2006; 12(3): 91-97

42. Safonov V.A., Ganichev A.F., Kim I.N., Khudashov V.G., Yakovlev D.O., Altarev A.S., Lukyanenko M.Yu. Experience with vascular biografts "KemAngioprotez" in reconstructive surgery of lower-limb major arteries. Angiologiya i sosudistaya khirurgiya 2009; 15(2): 103-106.

43. Sukovatih B.S., Sidorov D.V., Belikov L.N., Bolomatov N.V. Comparative effectiveness of autovenous transplantat with destructed valves and biological prostheses in femoral-popliteal positions in the critical ischemia of lower extremities treatment. Vestnik natsional'nogo medikokhirurgicheskogo tsentra im. N.I. Pirogova 2016; 11(3): 71-75.

44. Sukovatykh B.S., Vedenev Y.I., Rodionov A.O. Comparative characteristics of the wound process in the arterial wall after implantation of synthetic and biological endoprostheses. Novosti khirurgii 2013; 21(3): 9-15.
45. Sukovatykh B.S., Belikov L.N., Sukovatykh M.B., Sidorov D.V. The choice of femoropopliteal bypass surgery below the knee joint gap. Annaly khirurgii 2016; 21(5): 312-320.

46. Tishchenko I.S., Zolkin V.N., Maksimov N.V., Korotkov I.N., Demidov I.Yu., Barzaeva M.A. Two-year results of infrainguinal reconstructions using autovenous shunts and xenografts. Angiologiya i sosudistaya khirurgiya 2016; 22(4): 130-136.

47. Barbarash L.S., Burkov N.N., Kudryavtseva Yu.A., Sizova I.N., Zhuravleva I.Yu. Metabolic and surgical predictors of restenoses and thromboses of biological grafts in the infrainguinal position. Angiologiya $i$ sosudistaya khirurgiya 2011; 17(1): 29-34.

48. Barbarash L.S., Burkov N.N., Kudryavtseva Yu.A., Anufriev A.I., Zhuravleva I.Yu. Comparative analysis of arterial bioprostheses with various antithrombotic modification. Angiologiya i sosudistaya khirurgiya 2012; 18(2): 21-25.

49. Burkov N.N., Burkova T.V., Veremeev A.V., Kudryavtseva Yu.A., Zhuravleva I.Yu. Metabolic and genetic predictors of restenosis and thrombosis of arterial bioprostheses in the femoropopliteal position. Angiologiya $i$ sosudistaya khirurgiya 2013; 19(3): 131-136.

50. Baguneid M.S., Seifalian A.M., Salacinski H.J., Murray D., Hamilton G., Walker M.G. Tissue engineering of blood vessels. Br J Surg 2006; 93(3): 282-290, https://doi. org/10.1002/bjs.5256.

51. Chlupác J., Filová E., Bacáková L. Blood vessel replacement: 50 years of development and tissue engineering paradigms in vascular surgery. Physiol Res 2009; 58(Suppl 2): S119-S139.

52. Sarkar S., Salacinski H.J., Hamilton G., Seifalian A.M. The mechanical properties of infrainguinal vascular bypass grafts: their role in influencing patency. Eur $J$ Vasc Endovasc Surg 2006; 31(6): 627-636, https://doi.org/10.1016/j. ejvs.2006.01.006.

53. Haruguchi H., Teraoka S. Intimal hyperplasia and hemodynamic factors in arterial bypass and arteriovenous grafts: a review. J Artif Organs 2003; 6(4): 227-235, https://doi. org/10.1007/s10047-003-0232-x.

54. Ballyk P.D., Walsh C., Butany J., Ojha M. Compliance mismatch may promote graft-artery intimal hyperplasia by altering suture-line stresses. J Biomech 1997; 31(3): 229-237, https://doi.org/10.1016/s0197-3975(97)00111-5.

55. Scharn D.M., Daamen W.F., van Kuppevelt T.H., van der Vliet J.A. Biological mechanisms influencing prosthetic bypass graft patency: possible targets for modern graft design. Eur J Vasc Endovasc Surg 2012; 43(1): 66-72, https://doi. org/10.1016/j.ejvs.2011.09.009.

56. John L.C.H. Biomechanics of coronary artery and bypass graft disease: potential new approaches. Ann Thorac Surg 2009; 87(1): 331-338, https://doi.org/10.1016/j. athoracsur.2008.07.023.

57. Piterina A.V., Cloonan A.J., Meaney C.L., Davis L.M., Callanan A., Walsh M.T., McGloughlin T.M. ECM-based materials in cardiovascular applications: inherent healing potential and augmentation of native regenerative processes. Int J Mol Sci 2009; 10(10): 4375-4417, https://doi.org/10.3390/ ijms10104375.

58. Wiles K., Fishman J.M., De Coppi P., Birchall M.A. The host immune response to tissue-engineered organs: current problems and future directions. Tissue Eng Part B Rev 2016; 22(3): 208-219, https://doi.org/10.1089/ten.teb.2015.0376. 
59. Dahl S.L.M., Blum J.L., Niklason L.E. Bioengineered vascular grafts: can we make them off-the-shelf? Trends Cardiovasc Med 2011; 21(3): 83-89, https://doi.org/10.1016/j. tcm.2012.03.004

60. Thomas L.V., Nair P.D. The effect of pulsatile loading and scaffold structure for the generation of a medial equivalent tissue engineered vascular graft. Biores Open Access 2013; 2(3): 227-239, https://doi.org/10.1089/biores.2013.0003.

61. Tallawi M., Rosellini E., Barbani N., Cascone M.G., Rai R., Saint-Pierre G., Boccaccini A.R. Strategies for the chemical and biological functionalization of scaffolds for cardiac tissue engineering: a review. J R Soc Interface 2015; 12(108): 20150254, https://doi.org/10.1098/rsif.2015.0254.

62. Ghasemi-Mobarakeh L., Prabhakaran M.P., Tian L., Shamirzaei-Jeshvaghani E., Dehghani L., Ramakrishna S. Structural properties of scaffolds: crucial parameters towards stem cells differentiation. World J Stem Cells 2015; 7(4): 728744, https://doi.org/10.1016/j.biomaterials.2008.08.007.

63. Liu J.Y., Swartz D.D., Peng H.F., Gugino S.F., Russell J.A., Andreadis S.T. Functional tissue-engineered blood vessels from bone marrow progenitor cells. Cardiovasc Res 2007; 75(3): 618-628, https://doi.org/10.1016/j. cardiores.2007.04.018.

64. Cho S.W., Lim S.H., Kim I.K., Hong Y.S., Kim S.S., Yoo K.J., Park H.Y., Jang Y., Chang B.C., Choi C.Y., Hwang K.C., Kim B.S. Small-diameter blood vessels engineered with bone marrow-derived cells. Ann Surg 2005; 241(3): 506-515, https://doi.org/10.1097/01.sla.0000154268. 12239.ed.

65. Matsumura G., Miyagawa-Tomita S., Shin'oka T., Ikada Y., Kurosawa H. First evidence that bone marrow cells contribute to the construction of tissue-engineered vascular autografts in vivo. Circulation 2003; 108(14): 1729-1734, https://doi.org/10.1161/01.cir.0000092165.32213.61.

66. Gong Z., Niklason L.E. Small-diameter human vessel wall engineered from bone marrow-derived mesenchymal stem cells (hMSCs). FASEB J 2008; 22(6): 1635-1648, https://doi. org/10.1096/fj.07-087924.

67. Mirza A., Hyvelin J.M., Rochefort G.Y., Lermusiaux P., Antier D., Awede B., Bonnet P., Domenech J., Eder V. Undifferentiated mesenchymal stem cells seeded on a vascular prosthesis contribute to the restoration of a physiologic vascular wall. J Vasc Surg 2008; 47(6): 1313-1321, https://doi. org/10.1016/j.jvs.2007.12.038.

68. Hashi C.K., Zhu Y., Yang G.Y., Young W.L., Hsiao B.S., Wang K., Chu B., Li S. Antithrombogenic property of bone marrow mesenchymal stem cells in nanofibrous vascular grafts. Proc Natl Acad Sci USA 2007; 104(29): 11915-11920, https://doi.org/10.1073/pnas.0704581104.

69. Nieponice A., Soletti L., Guan J., Hong Y., Gharaibeh B., Maul T.M., Huard J., Wagner W.R., Vorp D.A. In vivo assessment of a tissue-engineered vascular graft combining a biodegradable elastomeric scaffold and muscle-derived stem cells in a rat model. Tissue Eng Part A 2010; 16(4): 12151223, https://doi.org/10.1089/ten.tea.2009.0427.

70. Hibino N., Duncan D.R., Nalbandian A., Yi T., Qyang Y., Shinoka T., Breuer C.K. Evaluation of the use of an induced puripotent stem cell sheet for the construction of tissueengineered vascular grafts. J Thorac Cardiovasc Surg 2012; 143(3): 696-703, https://doi.org/10.1016/j.jtcvs.2011.06.046.

71. Wang Y., Hu J., Jiao J., Liu Z., Zhou Z., Zhao C., Chang L.J., Chen Y.E., Ma P.X., Yang B. Engineering vascular tissue with functional smooth muscle cells derived from human iPS cells and nanofibrous scaffolds. Biomaterials 2014; 35(32): 8960-8969, https://doi.org/10.1016/j.biomaterials. 2014.07.011.

72. Heydarkhan-Hagvall S., Schenke-Layland $K$., Yang J.Q., Heydarkhan S., Xu Y., Zuk P.A., MacLellan W.R., Beygui R.E. Human adipose stem cells: a potential cell source for cardiovascular tissue engineering. Cells Tissues Organs 2008; 187(4): 263-274, https://doi.org/10.1159/000113407.

73. Zhang P., Moudgill N., Hager E., Tarola N., Dimatteo C., Mcllhenny S., Tulenko T., DiMuzio P.J. Endothelial differentiation of adipose-derived stem cells from elderly patients with cardiovascular disease. Stem Cells Dev 2011; 20(6): 977-988, https://doi.org/10.1089/scd.2010.0152.

74. He Y., Lu F. Development of synthetic and natural materials for tissue engineering applications using adipose stem cells. Stem Cells Int 2016; 2016: 5786257, https://doi. org/10.1155/2016/5786257.

75. Syedain Z.H., Meier L.A., Bjork J.W., Lee A., Tranquillo R.T. Implantable arterial grafts from human fibroblasts and fibrin using a multi-graft pulsed flowstretch bioreactor with noninvasive strength monitoring. Biomaterials 2011; 32(3): 714-722, https://doi.org/10.1016/j. biomaterials.2010.09.019.

76. Syedain Z.H., Meier L.A., Lahti M.T., Johnson S.L., Tranquillo R.T. Implantation of completely biological engineered grafts following decellularization into the sheep femoral artery. Tissue Eng Part A 2014; 20(11-12): 1726-1734, https://doi. org/10.1089/ten.tea.2013.0550.

77. Dahl S.L., Kypson A.P., Lawson J.H., Blum J.L., Strader J.T., Li Y., Manson R.J., Tente W.E., DiBernardo L., Hensley M.T., Carter R., Williams T.P., Prichard H.L., Dey M.S., Begelman K.G., Niklason L.E. Readily available tissueengineered vascular grafts. Sci Transl Med 2011; 3(68): 68ra9, https://doi.org/10.1126/scitranslmed.3001426.

78. McAllister T.N., Maruszewski M., Garrido S.A., Wystrychowski W., Dusserre N., Marini A., Zagalski K., Fiorillo A., Avila H., Manglano X., Antonelli J., Kocher A., Zembala M., Cierpka L., de la Fuente L.M., L'heureux N. Effectiveness of haemodialysis access with an autologous tissue-engineered vascular graft: a multicentre cohort study. Lancet 2009; 373(9673): 1440-1446, https://doi.org/10.1016/ s0140-6736(09)60248-8.

79. Yao L., Liu J., Andreadis S.T. Composite fibrin scaffolds increase mechanical strength and preserve contractility of tissue engineered blood vessels. Pharm Res 2008; 25(5): 1212-1221, https://doi.org/10.1007/s11095-007-9499-6.

80. Lamm P., Juchem G., Milz S., Schuffenhauer M., Reichart B. Autologous endothelialized vein allograft a solution in the search for small-caliber grafts in coronary artery bypass graft operations. Circulation 2001; 104(12 Suppl 1): I108-I114, https://doi.org/10.1161/hc37t1.094527.

81. Mironov V., Kasyanov V., Markwald R.R. Nanotechnology in vascular tissue engineering: from nanoscaffolding towards rapid vessel biofabrication. Trends Biotechnol 2008; 26(6): 338-344, https://doi.org/10.1016/j tibtech.2008.03.001.

82. Mickevicius T., Pockevicius A., Kucinskas A., Gudas R., Maciulaitis J., Noreikaite A., Usas A. Impact of storage conditions on electromechanical, histological and histochemical properties of osteochondral allografts. BMC Musculoskelet Disord 2015; 16(1): 314, https://doi.org/10.1186/ s12891-015-0776-y.

83. Nover A.B., Stefani R.M., Lee S.L., Ateshian G.A., 
Stoker A.M., Cook J.L., Hung C.T. Long-term storage and preservation of tissue engineered articular cartilage. J Orthop Res 2016; 34(1): 141-148, https://doi.org/10.1002/jor.23034.

84. Zhang P., Policha A., Tulenko T., DiMuzio P. Autologous human plasma in stem cell culture and cryopreservation in the creation of a tissue-engineered vascular graft. J Vasc Surg 2016; 63(3): 805-814, https://doi.org/10.1016/j. jvs.2014.10.015.

85. Martin I., Wendt D., Heberer M. The role of bioreactors in tissue engineering. Trends Biotechnol 2004; 22(2): 80-86, https://doi.org/10.1016/j.tibtech.2003.12.001.

86. Niklason L.E., Langer R. Advances in tissue engineering of blood vessels and other tissues. Transpl Immunol 1997; 5(4): 303-306, https://doi.org/10.1016/s0966-3274(97)80013-5.

87. Zilla P., Fasol R., Deutsch M., Fischlein T., Minar E., Hammerle A., Krupicka O., Kadletz M. Endothelial cell seeding of polytetrafluoroethylene vascular grafts in humans: a preliminary report. J Vasc Surg 1987; 6(6): 535-541, https:// doi.org/10.1016/0741-5214(87)90266-7.

88. Deutsch M., Meinhart J., Vesely M., Fischlein T., Groscurth P., von Oppell U., Zilla P. In vitro endothelialization of expanded polytetrafluoroethylene grafts: a clinical case report after 41 months of implantation. J Vasc Surg 1997; 25(4): 757763, https://doi.org/10.1016/s0741-5214(97)70307-0.

89. Deutsch M., Meinhart J., Zilla P., Howanietz N., Gorlitzer M., Froeschl A., Stuempflen A., Bezuidenhout D., Grabenwoeger M. Long-term experience in autologous in vitro endothelialization of infrainguinal ePTFE grafts. J Vasc Surg 2009; 49(2): 352-362, https://doi.org/10.1016/j. jvs.2008.08.101.

90. Moroni F., Mirabella T. Decellularized matrices for cardiovascular tissue engineering. Am J Stem Cells 2014; 3(1): $1-20$.

91. Spark J.I., Yeluri S., Derham C., Wong Y.T., Leitch D. Incomplete cellular depopulation may explain the high failure rate of bovine ureteric grafts. Br J Surg 2008; 95(5): 582-585, https://doi.org/10.1002/bjs.6052.

92. Kasimir M.T., Rieder E., Seebacher G., Nigisch A., Dekan B., Wolner E., Weigel G., Simon P. Decellularization does not eliminate thrombogenicity and inflammatory stimulation in tissue-engineered porcine heart valves. J Heart Valve Dis 2006; 15(2): 278-286.

93. Baiguera S., Urbani L., Del Gaudio C. Tissue engineered scaffolds for an effective healing and regeneration: reviewing orthotopic studies. Biomed Res Int 2014; 2014: 398069, https://doi.org/10.1155/2014/398069.

94. Thottappillil N., Nair P.D. Scaffolds in vascular regeneration: current status. Vasc Health Risk Manag 2015; 11: 79-91, https://doi.org/10.2147/vhrm.s50536.

95. Koch S., Flanagan T.C., Sachweh J.S., Tanios F., Schnoering H., Deichmann T., Ellä V., Kellomäki M., Gronloh N., Gries T., Tolba R., Schmitz-Rode T., Jockenhoevel S. Fibrinpolylactide-based tissue-engineered vascular graft in the arterial circulation. Biomaterials 2010; 31(17): 4731-4739, https://doi.org/10.1016/j.biomaterials.2010.02.051.

96. Wise S.G., Byrom M.J., Waterhouse A., Bannon P.G., Weiss A.S., Ng M.K. A multilayered synthetic human elastin/ polycaprolactone hybrid vascular graft with tailored mechanical properties. Acta Biomater 2011; 7(1): 295-303, https://doi. org/10.1016/j.actbio.2010.07.022.

97. Lu G., Cui S.J., Geng X., Ye L., Chen B., Feng Z.G., Zhang J., Li Z.Z. Design and preparation of polyurethanecollagen/heparin-conjugated polycaprolactone double-layer bionic small-diameter vascular graft and its preliminary animal tests. Chin Med J (Engl) 2013; 126(7): 1310-1316.

98. McMahon R.E., Qu X., Jimenez-Vergara A.C., Bashur C.A., Guelcher S.A., Goldstein A.S., Hahn M.S. Hydrogel-electrospun mesh composites for coronary artery bypass grafts. Tissue Eng Part C Methods 2011; 17(4): 451461, https://doi.org/10.1089/ten.tec.2010.0427.

99. Sin D., Miao X., Liu G., Wei F., Chadwick G., Yan C., Friis T. Polyurethane (PU) scaffolds prepared by solvent casting/particulate leaching (SCPL) combined with centrifugation. Materials Science and Engineering: C 2010; 30(1): 78-85, https://doi.org/10.1016/j.msec.2009.09.002.

100. Iwasaki K., Kojima K., Kodama S., Paz A.C., Chambers M., Umezu M., Vacanti C.A. Bioengineered threelayered robust and elastic artery using hemodynamicallyequivalent pulsatile bioreactor. Circulation 2008; 118(14 Suppl): S52-S57, https://doi.org/10.1161/circulationaha.107.757369.

101. Pham Q.P., Sharma U., Mikos A.G. Electrospinning of polymeric nanofibers for tissue engineering applications: a review. Tissue Eng 2006; 12(5): 1197-1211, https://doi. org/10.1089/ten.2006.12.1197.

102. Peck M., Gebhart D., Dusserre N., McAllister T.N., L'Heureux N. The evolution of vascular tissue engineering and current state of the art. Cells Tissues Organs 2012; 195(1-2): 144-158, https://doi.org/10.1159/000331406.

103. Norotte C., Marga F.S., Niklason L.E., Forgacs G. Scaffold-free vascular tissue engineering using bioprinting. Biomaterials 2009; 30(30): 5910-5917, https://doi. org/10.1016/j.biomaterials.2009.06.034.

104. Swartz D.D., Andreadis S.T. Animal models for vascular tissue-engineering. Curr Opin Biotechnol 2013; 24(5): 916-925, https://doi.org/10.1016/j.copbio.2013.05.005.

105. Byrom M.J., Bannon P.G., White G.H., Ng M.K. Animal models for the assessment of novel vascular conduits. J Vasc Surg 2010; 52(1): 176-195, https://doi.org/10.1016/j. jvs.2009.10.080.

106. Rashid S.T., Salacinski H.J., Hamilton G., Seifalian A.M. The use of animal models in developing the discipline of cardiovascular tissue engineering: a review. Biomaterials 2004; 25(9): 1627-1637, https://doi.org/10.1016/ s0142-9612(03)00522-2.

107. Peng H., Schlaich E.M., Row S., Andreadis S.T., Swartz D.D. A novel ovine ex vivo arteriovenous shunt model to test vascular implantability. Cells Tissues Organs 2012; 195(1-2): 108-121, https://doi.org/10.1159/000331415.

108. Bertram T.A., Tentoff E., Johnson P.C., Tawil B., Van Dyke M., Hellman K.B. Hurdles in tissue engineering/ regenerative medicine product commercialization: a pilot survey of governmental funding agencies and the financial industry. Tissue Eng Part A 2012; 18(21-22): 2187-2194, https://doi.org/10.1089/ten.tea.2012.0186.

109. Jaklenec A., Stamp A., Deweerd E., Sherwin A., Langer R. Progress in the tissue engineering and stem cell industry "are we there yet?" Tissue Eng Part B Rev 2012; 18(3): 155-166, https://doi.org/10.1089/ten.teb.2011.0553.

110. Tillman B., Hardin-Young J., Shannon W., Russell A.J., Parenteau N.L. Meeting the need for regenerative therapies: translation-focused analysis of U.S. regenerative medicine opportunities in cardiovascular and peripheral vascular medicine using detailed incidence data. Tissue Eng Part B Rev 2013; 19(2): 99-115, https://doi.org/10.1089/ten. teb.2011.0678.

111. Parenteau N.L. Driving the bumpy road to 


\section{REVIEWS}

commercialization. Tissue Eng Part A 2014; 20(11-12): 15631564, https://doi.org/10.1089/ten.tea.2014.0012.

112. Chernonosova V.S., Kvon R.I., Kiseleva E.V., Stepanova A.O., Laktionov P.P. Investigation of the surface layer of 3D-matrices for tissue engineering. Biomeditsinskaya khimiya 2017; 63(1): 32-38.

113. Antonova L.V., Seifalian A.M., Kutikhin A.G.,
Sevostyanova V.V., Krivkina E.O., Mironov A.V., Burago A.Y., Velikanova E.A., Matveeva V.G., Glushkova T.V., Sergeeva E.A., Vasyukov G.Y., Kudryavtseva Y.A., Barbarash O.L., Barbarash L.S. Bioabsorbable bypass grafts biofunctionalised with RGD have enhanced biophysical properties and endothelialisation tested in vivo. Front Pharmacol 2016; 7: 136, https://doi.org/10.3389/fphar.2016.00136. 